\title{
PARTIAL MONOSOMY 5p AND PARTIAL TRISOMY 5q DUE TO PATERNAL PERICENTRIC INVERSION 5(p15.1q35.1)
}

\author{
Tohru Sonoda, Kenji Kawaguchi, Ken-ichi OHBa, \\ Harumichi Madokoro, and Shozo OHdo \\ Department of Pediatrics, Miyazaki Medical College, \\ Kiyotake-cho, Miyazaki 889-16, Japan
}

\begin{abstract}
Summary A male infant with karyotype 46,XY,rec(5),dup q,inv(5)(p15.1 q35.1)pat is presented. The proband showed growth and developmental retardation, complex cardiovascular abnormalities, inguinal hernia and microcephaly in addition to facial appearance and cat-like cry characteristic of the cri-du-chat syndrome. Growth and developmental retardation, and microcephly noted in this patient were markedly more serious than those observed in patients either with partial monosomy $5 p$ or with partial trisomy $5 \mathrm{q}$ alone.
\end{abstract}

Key Words pericentric inversion, recombinant chromosome, double segmental aneuploidy, partial monosomy $5 \mathrm{p}$, partial trisomy $5 \mathrm{q}$

\section{INTRODUCTION}

In cases with double segmental aneuploidy produced by parental balanced translocation or inversion, the aneuploidy responsible for the phenotype is often unclear. The case reported in this paper suggests the following: 1) Even in a case with very small distal trisomy $5 \mathrm{q}(5 \mathrm{q} 35.1 \rightarrow$ qter $)$, features characteristic of partial trisomy 5q are shown; 2) Phenotype of this double segmental aneuploidy is classified as belonging to the composite phenotype category; 3) Because of the synergistic effect of double segmental aneuploidy, in our patient the phenotype of partial trisomy $5 q$ and partial monosomy $5 p$ combined was severer than in cases with single aneuploidies.

\section{CLINICAL AND CYTOGENETIC FINDINGS}

The proband, a male infant, was born April 23, 1987 after 36 weeks' gestation

Received February 6, 1989; revised version received March 30, 1989; Accepted May 16, 1989 
to healthy and first-cousin parents, both aged 29. The mother's first pregnancy ended in a spontaneous first trimester abortion of twins. The birth weight of the proband was $1,458 \mathrm{~g}$, length $45 \mathrm{~cm}$ and head circumference, $28 \mathrm{~cm}$. Apgar scores were 8 and 9 at one and five minutes, respectively. On account of intrauterine growth retardation, multiple congenital anomalies and cat-like cry, he was referred to our outpatient clinic on the next day after birth. Physical findings included the following: flat occiput, frontal hypertrichosis, micrognathia, laterally downward slanting palpebral fissures, telecanthus, flatness of nasal bridge, malformed pinnae (prominent anthelix), bilateral fistula of the auricle, thin upper lip, and high-arched palate. A characteristic cry like the mewing of a kitten and heart murmurs were audible. A large inguinal hernia was observed on the left. Small penis, clinodactyly of the 5th fingers and muscular hypotonia were noted. Dermatoglyphic study revealed ten whorls on the fingers, and a simian crease on the left palm. The atd angle was $60^{\circ}$ on the right palm and $50^{\circ}$ on the left. There was no thenar pattern.

Echocardiography and cardiac catheterization showed complex cardiovascular abnormalities consisting of double outlet right ventricle, ventricular septal defect, pulmonary stenosis and bicuspid aortic valve. His and his parents' chromosomes were analyzed on cultured lymphocytes. The father's karyotype was 46,XY,inv (5)(p15.1q35.1) and that of the proband was 46,XY,rec(5),dup q,inv(5)(p15.1q35.1)

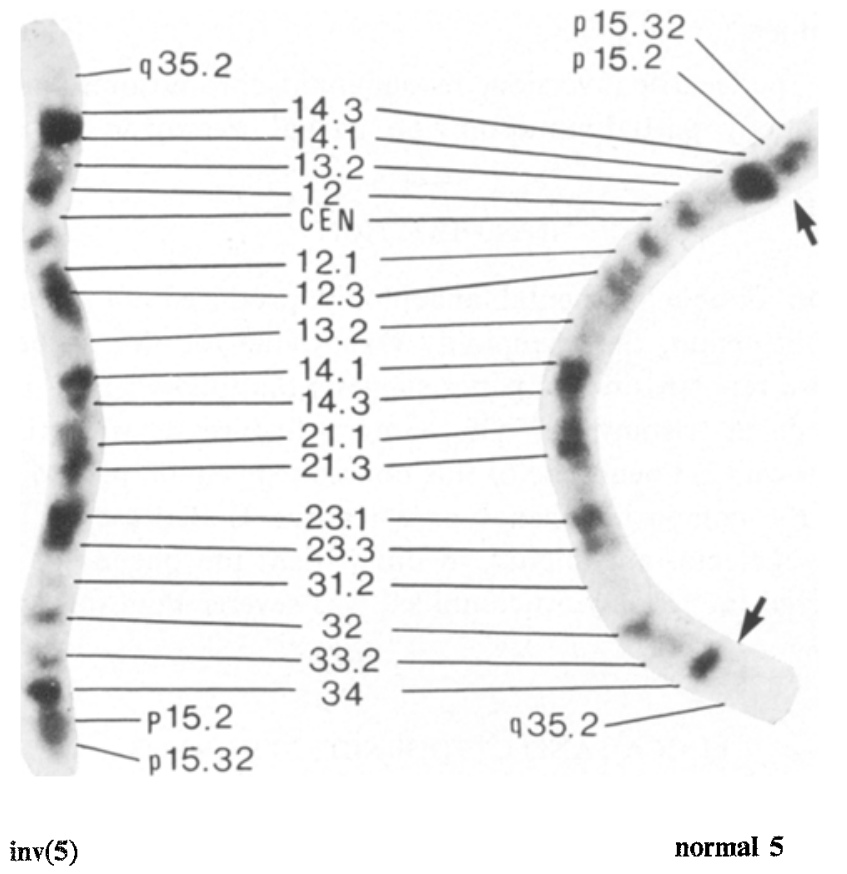

Fig. 1. Partial karyotype of the father. Arrows indicate the break points of $5 \mathrm{p} 15.1$ and 5q35.1, respectively. 


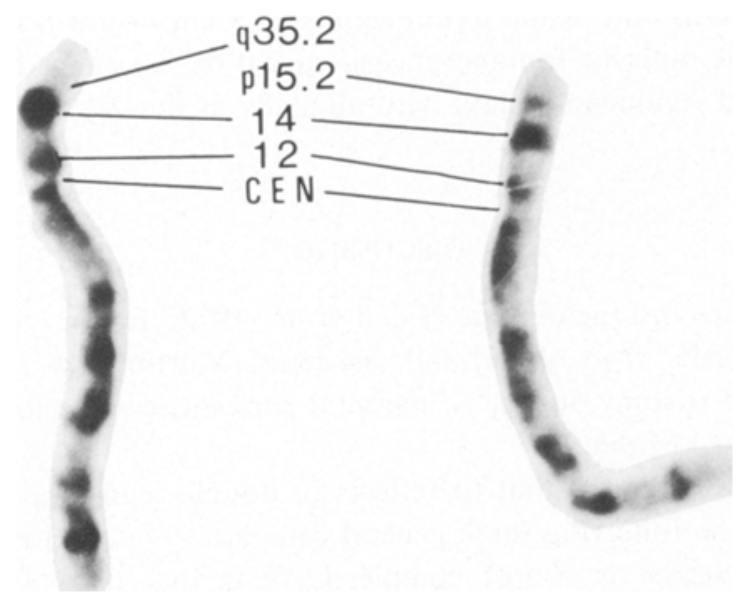

Fig. 2. Partial karyotype of the proband.

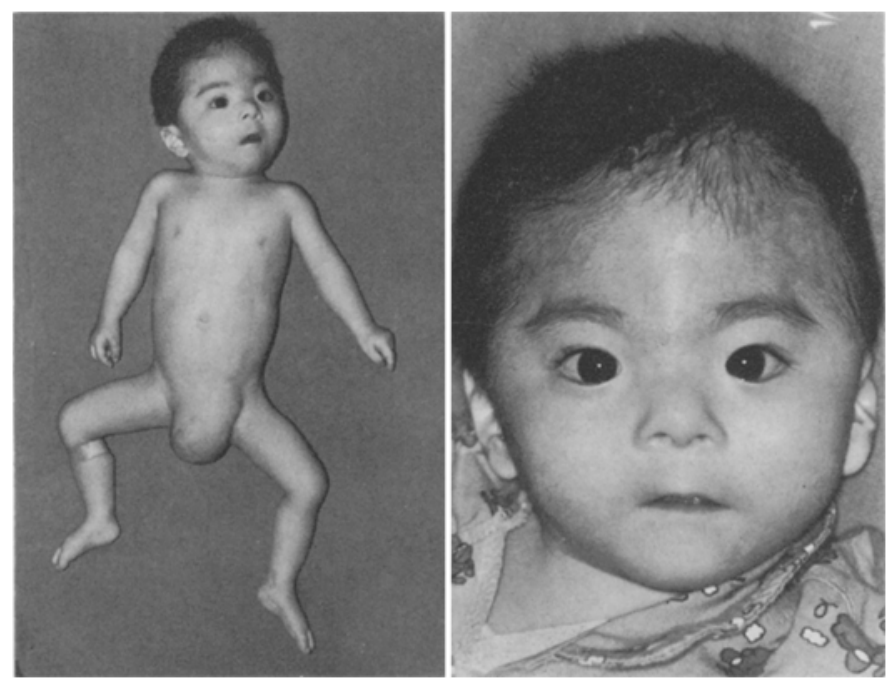

Fig. 3. Proband at 1 year 6 months.

pat, representing a duplication of the distal portion $5 \mathrm{q}(5 \mathrm{q} 35.1 \rightarrow \mathrm{qter})$ and a deletion of $5 \mathrm{p}(5 \mathrm{p} 15.1 \rightarrow \mathrm{pter})$ (Figs. 1 and 2 ).

Since the patient had congestive heart failure and recurrent respiratory tract infection after admission, administration of antibiotics, cordials and diuretics as well as treatment with oxygenation, fluid infusion and tube feeding were required. At the age of one year and six months his weight was $4,290 \mathrm{~g}(-5.8$ S.D.), length 
$59.0 \mathrm{~cm}$ ( -7.6 S.D.), and head circumference $35.3 \mathrm{~cm}$ (-7.8 S.D.). The mewing cry persisted. The anterior fontanel measured 2.0 by $2.0 \mathrm{~cm}$. The developmental assessment showed significant delay, with all skills at the 2 to 3 months level (Fig. 3).

\section{DISCUSSION}

So far, six cases in four families (Faed et al., 1972; Ebbin et al., 1979; Beemer et al., 1984; Schroeder et al., 1986) and one fetus (Martin et al., 1988) with partial monosomy $5 \mathrm{p}$ and trisomy $5 \mathrm{q}$ due to parental pericentric inversion of chromosome 5 have been reported (Table 1).

Epstein (1986) suggested that the effects of double segmental aneuploidy could be classified into the following three general categories: 1) one in which the phenotype derives completely or almost completely from that of one of the segmental aneuploidies; 2) one characterized by the presence of some of the features of each of the contributing imbalances; 3) those cases in which the phenotype is a reasonable composite of the individual segmental aneuploid phenotype. Since all the patients excluding two cases (Schroeder et al., 1986; Martin et al., 1988), as well as our case, showed clinical features of partial monosomy $5 p$ and partial trisomy $5 \mathrm{q}$, this double segmental aneuploidy can be classified as a third composite phenotype category which was termed by Carlin and Norman (1978) as a "phenotype hybrid." Among the features noted in our case, severe and complex heart abnormalities, and inguinal hernia were occasioned by partial trisomy 5q, whereas the cat-like cry and dermatoglyphics were presumed to caused by partial monosomy 5p (Beemer et al., 1984). Although heart disease and inguinal hernia are sometimes noted in patients with partial monosomy $5 \mathrm{p}$, the incidence is not high, and the severity is not as serious as in partial trisomy $5 \mathrm{q}$ cases. According to the review of the cases of partial trisomy $5 \mathrm{q}$ conducted by Rodewald et al. (1980), congenital heart disease and inguinal hernia were characteristic of partial trisomy $5 q$.

The combination of two segmental aneuploidies that exhibit certain features in common does not generally lead to an exaggerated expression of those features

Table 1. Profiles of the present case and previously reported cases.

\begin{tabular}{lcccccc} 
Authors & $\begin{array}{c}\text { Faed } \\
(1972)\end{array}$ & $\begin{array}{c}\text { Ebbin } \\
(1979)\end{array}$ & $\begin{array}{c}\text { Beemer } \\
(1984)\end{array}$ & $\begin{array}{c}\text { Schroeder } \\
(1986)\end{array}$ & $\begin{array}{c}\text { Martin } \\
(1988)\end{array}$ & $\begin{array}{c}\text { Present } \\
\text { case }\end{array}$ \\
\hline Carriers & Mother & Father & Father & Father & Mother & Father \\
\hline Break points & $\mathrm{p} 13$ & $\mathrm{p} 14.2$ & $\mathrm{p} 15.1$ & $\mathrm{p} 15$ & $\mathrm{p} 13$ & $\mathrm{p} 15.1$ \\
& $\mathrm{q} 33$ & $\mathrm{q} 33$ & $\mathrm{q} 33.3$ & $\mathrm{q} 32$ & $\mathrm{q} 33$ & $\mathrm{q} 35.1$ \\
\hline Sex of probands & 1 Male & 1 Male & $\begin{array}{l}\text { 1 Male } \\
\text { 2 Females }\end{array}$ & & & \\
\end{tabular}


(Epstein, 1986). However, growth and developmental retardation, and microcephaly were extremely severe in our case. A mother and son who had the karyotype of $\operatorname{del}(5)(\mathrm{p} 15.1 \rightarrow$ pter $)$ reported by Kushnick et al. (1984) did not have severe mental and growth retardation, and microcephaly ordinarily noted in cases with the cri-du-chat syndrome. Accordingly, these authors presumed that as the size of $5 \mathrm{p}$ deletion becomes smaller, the severity of mental and growth retardation becomes milder. Furthermore, it was pointed out that the intelligence of individuals with partial monosomy $5 \mathrm{p}$ was negatively correlated with the size of the deletion (Wilkins et al., 1983; Carlin and Neadle, 1978), and that individuals with larger deletions tended to have a smaller head size (Niebuhr, 1978; Wilkins et al., 1983) and severe growth retardation (Wilkins et al., 1983). On the other hand, in terminal duplications of $5 \mathrm{q}$, longer duplications ( $5 \mathrm{q} 31$ or $33 \rightarrow$ qter) had severer growth retardation, developmental retardation, and microcephly than shorter $(5 \mathrm{q} 34 \rightarrow \mathrm{qter})$ ones (Rodewald et al., 1980).

It has been noted that carriers of the balanced inversion chromosome 5 are fathers in most cases (Table 1). Although too few cases are reported for exact estimates, reasons advanced have been that male carriers might be more fertile than female carriers (Faed et al., 1972). Furthermore it was suggested that when the mother is heterozygous this inversion may be associated with infertility (Martin et al., 1988). Although there might be some exceptions, small inversions generally have a much better genetic prognosis than large inversions. In other words, the general rule is that large inversions give rise to recombinant chromosomes and greater risk of abortion (Romain et al., 1982). This rule also applies to chromosome 5. In a family involved with a large pericentric inversion 5 (5p15.1q33.3) reported by Beemer et al. (1984), there were three affected children, two normal children, one carrier, and four abortions. In the family reported in this paper, there was one affected child and one intrauterine death. The male-to-female ratio of the cri-du-chat syndrome is 139:192 (Niebuhr, 1978), and that of partial trisomy $5 \mathrm{q}$ is 4:10 (Rodewald et al., 1980). But among reported partial trisomy $5 \mathrm{q}$ and partial monosomy $5 \mathrm{p}$ cases, including ours, the number of male patients was high $(\mathrm{M}: \mathrm{F}=$ $6: 2$ ). The reason for a preponderence of males is unknown: it may be due to an excess of female abortions, or a higher mortality rate in females. The fact that the dup $p($ del $q)$ recombinant has not been recognized, although the dup $q($ del $p)$ recombinant is reported, is also quite interesting. The former one may represent a complement generally leading to gamatic or zygotic lethality that may not be clinically recognizable (Martin et al., 1988).

\section{REFERENCES}

Beemer, F.A., DeFrance, H.F., Rosina-Angelista, I.J.M., Gerards, L.J., Cats, B.P. and Guyt, R. 1984. Familial partial monosomy $5 \mathrm{p}$ and trisomy $5 \mathrm{q}$ : three cases due to paternal pericentric inversion 5(p151q333). Clin. Genet. 26: 209-215.

Carlin, M.E. and Neadle, M.M. 1978. Cri-du-chat syndrome-a correlation between abnormalies 
and size of deletion. Birth Defects Orig. Art. Ser. 14(6C): 428-429.

Carlin, M.E. and Norman, C. 1978. Partial trisomy 12p associated with 4p deletion due to paternal $\mathrm{t}(12 \mathrm{p}-; 4 \mathrm{p}+)$ translocation. Birth Defects Orig. Art. Ser. 14(6C): 399-406.

Ebbin, A.J., Wilson, M.G. and Towner, J.H. 1979. Recombinant of inversion 5. Clin. Res. 27: 103A.

Epstein, C.J. 1986. The consequences of chromosome imbalance. Principles, Mechanisms, and Models. Cambridge University Press, New York, pp. 12-61.

Faed, M.J.W., Marrian, V.J., Robertson, J., Robson, E.B. and Cook, P.J.L. 1972. Inherited pericentric inversion of chromosome 5: a family with history of neonatal death and a case of the "cri du chat" syndrome. Cytogenet. 11: 400-411.

Kushnick, T., Rao, K.W. and Lamb, A.N. 1984. Familial 5p- syndrome. Clin. Genet. 26: 472-476.

Martin, A.O., Northrup, H., Ledbetter, D.H., Trask, B., van'den'Engh, G., Le Beau, M.M., Beaudet, A.L., Gray, J.W., Sekhon, G., Krassikoff, N. and Booth, C. 1988. Prenatal detection of 46,XY, rec(5), dup q,inv(5)(p13q33) using DNA analysis, flow cytometry, and in situ hybridization to supplement classical cytogenetic analysis. Am. J. Med. Genet. 31: 643-654.

Niebuhr, E. 1978. The cri du chat syndrome. Epidemiology, cytogenetics, and clinical features. Hum. Genet. 44: 227-275.

Rodewald, A., Zank, M., Gley, E.O., and Zang, K.D. 1980. Partial trisomy 5q: three different phenotypes depending on different duplication segments. Hum. Genet. 55: 191-198.

Romain, D.R., Chapman, C.J., Columbano-Green, L., Smythe, R.H. and Gebbie, O. 1982. Two pericentric inversions, inv(2)(p11q13) and inv(5)(p13q13), in a patient referred for psychiatric problems. I. Med. Genet. 19: 153-155.

Schroeder, H.W.J., Forbes, S., Mach, L., Davis, S. and Norwood, T.H. 1986. Recombination aneusomy of chromosome 5 associated with multiple severe congenital malformations. Clin. Genet. 30: 285-292.

Wilkins, L.E., Brown, J.A., Nance, W.E. and Wolf, B. 1983. Clinical heterogeneity in 80 homereared children with cri du chat syndrome. J. Pediatr. 102: 528-533. 